\title{
SOSIALISASI PROSEDUR DAN PENGEMBANGAN OPEN JOURNAL SYSTEM INDONESIAN JOURNAL OF PEACE AND SECURITY STUDIES (IJPSS) PROGRAM STUDI HUBUNGAN INTERNASIONAL UNIVERSITAS MATARAM
}

\author{
(The Socialization of Procedure and Development Open Journal System Indonesian \\ Journal of Peace and Security Studies (IJPSS) Department of International Relations \\ Mataram University)
}

\author{
Ridho Ilahi ${ }^{[1]}$, Nadiyasari Agitha ${ }^{[1]}$, Mala Mardialina ${ }^{[2]}$ \\ ${ }^{[1]}$ Dept Informatics Engineering, Mataram University \\ Jl. Majapahit 62, Mataram, Lombok NTB, INDONESIA \\ ${ }^{[2]}$ Dept International Relations, Mataram University \\ Jl. Majapahit 62, Mataram, Lombok NTB, INDONESIA \\ Email: ridhoilahi0220@gmail.com; [nadiya,mala.mardialina]@unram.ac.id
}

\begin{abstract}
Abstrak
Perkembangan teknologi di era globalisasi menimbulkan perubahan yang signifikan terlebih lagi dalam menyebarkan dan mendapatkan infomasi. Salah satu teknologi yang sangat berpengaruh dalam menyebarkan dan mendapatkan informasi adalah internet dan website. Indonesian journal of peace and security (IJPSS) merupakan sistem berbasis website yang menggunakan framework Open Journal System (OJS) yang digunakan untuk mengelola dan menerbitkan e-jurnal hasil penelitian Program Studi Hubungan Internasional Universitas Mataram. Dalam proses pengelolaan dan penerbitan e-journal sistem IJPSS masih dilakukan diluar sistem OJS, ini dikarenakan minimnya pengetahuan pengelola IJPSS mengenai OJS. Pada penulisan ini akan membahas bagaimana prosedur penerbitan e-jurnal dan membahas fiturfitur pendukung dari proses publikasi e-journal. Dalam proses pengembangan sistem IJPSS dibutuhkan metode pengembangan yang memungkinkan client dan pengembang dapat berintraksi dalam mengembangkan sistem tersebut, hal ini disebabkan dalam pengolahan prosedur dan pengembangan fitur dibutuhkan pendapat dari client. Metode prototyping adalah metode yang memiliki konsep yang sama dengan kebutuhan tersebut dimana konsep metode prototyping didasarkan kepuasan dan kesesuain dari client. Berdasarkan sistem yang sudah dikembangkan, dilakukan pengujian oleh pengelola IJPSS sebagai responden untuk mendapatkan hasil kepuasan pengelola. Hasil dari evaluasi terdapat $100 \%$ responden setuju dengan sistem yang sudah di kembangkan.
\end{abstract}

Keywords: Open Journal Sistem, Sistem Informasi, Metode Prototyping, Teknologi Informasi, E-Journal.

\section{Pendahuluan}

Perkembangan teknologi di era globalisasi menimbulkan perubahan yang signifikan terlebih lagi dalam menyebarkan dan mendapatkan suatu infomasi. Salah satu teknologi yang sangat berpengaruh dalam menyebarkan dan mendapatkan suatu informasi adalah internet, yang mana internet merupakan suatu jaringan global yang terhubung dengan seluruh komputer di dunia [1]. Internet pada era globalisasi dapat dilihat dari banyaknya bidang kehidupan yang menggunakan teknologi internet seperti pada bidang sosial, pendidikan, ekonomi, komersial, hingga pemerintahan. Salah satu bidang yang perkembangannya di pengaruhi oleh internet adalah bidang pendidikan. Dengan adanya internet, penyebaran, pertukaran, dan pengambilan suatu informasi saat ini lebih mudah dilakukan. Perkembangan internet pada pada dunia pendidikan salah satunya digunakan sebagai media publikasi karya ilmiah. Saat ini, telah banyak penulis yang mempublikasikan karya tulisnya melalui media internet. Hal ini dilakukan karena dirasa lebih efisien untuk dibandingkan dengan media cetak.

Saat ini telah banyak berkembang situs atau website yang menyediakan layanan untuk publikasi ilmiah. Terkhusus untuk karya ilmiah berupa jurnal, terdapat sebuah sistem untuk pengelolaan jurnal bernama OJS (Open Jurnal System). OJS merupakan sistem aplikasi yang berfungsi untuk menerbitkan dan mengolah jurnal ilmiah secara online yang berbasis open source[2]. Sistem aplikasi berbasis web ini memungkinkan sebuah jurnal ilmiah dipublikasikan secara resmi melalui media internet. Dalam pengelolaan jurnal mulai dari penerimaan manuscript oleh editor, proses reviewing, tracking, dan sebagainya hingga manuscript tersebut diterima dan publish pada sebuah 
edisi jurnal, sistem OJS sebagai framework pengelola jurnal ilmiah secara online menyediakan keleluasaan bagi pengelola jurnal dalam pengelolaan[3]. Dalam dunia Pendidikan terutama universitas, penggunaan OJS dapat mempermudah dalam merekam jejak history dari hasil penelitian dosen dan mahasiswa yang di implemtasi-kan dalam bentuk jurnal ilmiah yang mana hasil penelitian dosen dan mahasiswa tersebut jika hasil penelitiannya terindeks pada database internasional, maka hal ini sangat memungkinkan untuk mengangkat nama dari instansi tersebut.

Program studi Hubungan Internasional Universitas Mataram merupakan salah satu instansi yang melakukan penelitian dalam bidang studi perdamaian dan keamanan (Peace and Security Studies) yang hasil penelitian dalam bentuk jurnal. Program studi Hubungan Internasional sendiri sudah mulai menerapkan sistem untuk pengolahan jurnal menggunakan OJS yang di beri nama website Indonesian Journal of Peace and Security Studies (IJPSS). Sistem IJPSS belum mampu menangani proses publikasi jurnal secara efisien. Pengelola IJPSS pernah mempublikasikan jurnal edisi pertama dimana dalam proses publikasi dari segi penerimaan manuscript oleh editor, proses reviewing masih di lakukan secara manual. Hal ini di sebabkan oleh segi sumber daya pengelola yang masih kurang memahami alur proses publikasi menggunakan OJS. Penyebab lainnya yang dari belum adanya manuscript template adalah dari pihak pengelola dan segi fitur yang ada pada website IJPSS masih dapat dikatakan kurang, mulai dari fitur pemberitahuan untuk pemberitahuan pembuatan edisi jurnal (Call for paper), fitur panduan publikasi, dan beberapa pengaturan beberapa tampilan, maka diperlukan pengembangan dari sistem OJS IJPSS. Dari beberapa permasalahan tersebut, dalam proses pengembangan sistem IJPSS sendiri dibutuhkan metode pengembangan yang memungkinkan client dan pengembang dapat berintraksi dalam mengembangkan sistem tersebut, hal ini di sebabkan dalam pengolahan prosedur, pengembangan fitur dan pengembangan beberapa tampilan di butuhkan pendapat dari client.

Metode prototyping merupakan salah satu metode yang didasarkan pada sebuah konsep working model. Pengembangan sistem dengan menggunakan Metode prototyping memungkinkan untuk client dan pengembang saling melakukan eksperimen untuk pengembangan sistem dengan tujuan kepuasan dan kesesuaian client. Maka dari itu akan dilakukan pengembangan terhadap sistem IJPSS antara lain pembuatan prosedur pengeloaan OJS, mengadakan sosialisasi kepada pengelola mengenai pengolalaan OJS, pembuatan manuscript template, menambahkan fitur announcement untuk Call for paper, fitur panduan publikasi, serta pengaturan tampilan. Sehingga sistem IJPSS mampu menangani proses publikasi jurnal secara online dengan efektif.

Tujuan Pengabdian Masyarakat pada Program Studi Hubungan Internasional Universitas Mataram antara lain sebagai berikut :

1. Mengetahui prosedur dari alur kerja dari sistem OJS,

2. Mengetahui fitur-fitur kebutuhan dari OJS kemudian membuatkan fitur-fitur yang masih kurang dalam sistem OJS IJPSS.

Pada Pengabdian Masyarakat ini, baik mahasiswa, ataupun instansi tempat dilaksanakannya Pengabdian Masyarakat mendapatkan beberapa manfaat, antara lain:

1. Untuk mahasiswa

- Menambah pengalaman dan pengetahuan mahasiswa mengenai dunia kerja yang sebenarnya.

- Mahasiswa dapat mengimplementasikan materi perkuliahan ke dalam Pengabdian Masyarakat ini.

- Mengetahui sejauh mana kemampuan mahasiswa menerapkan ilmunya yang telah didapatkan.

- Mengetahui tata cara pengelolaan website dengan OJS.

2. Untuk Program Studi Hubungan Internasional

- Membantu instansi dalam pengembangan website penguggahan jurnal dalam bidangan studi perdamaian dan keamanan.

- Membantu instansi dalam memublikasikan jurnal hasil penelitian melalui media internet.

- Merasa terbantu dalam hal pengembangan teknologi informasi.

\section{Tinjauan Pustaka}

\subsection{Internet}

Internet merupakan suatu jaringan global yang munghungkan suatu komputer dengan seluruh komputer di dunia. Internet dapat memungkinkan sebuah komputer mengakases data selama 24 jam yang ada pada komputer yang berada di benua yang berbeda tanpa henti dan juga dapat merekam suatu kejadian penting di suatu daerah atau 
negara yang kemudian kejadian tersebut bisa diketahui secara cepat oleh orang pada daerah atau negara yang berbeda [1].

\subsection{Open Journal Syestem}

Open Journal System (OJS) merupakan sistem aplikasi yang berfungsi untuk menerbitkan dan mengolah jurnal ilmiah secara online yang berbasis open source. Dalam menajemen jurnal, OJS merupakan salah satu aplikasi berbasis web yang dapat jalankan secara mudah dalam proses penerbitan jurnal. OJS merupakan aplikasi yang memang dirancang berfungsi untuk meminimalisir waktu pengerjaan dan energi dalam mengelola administrasi dan manajerial yang berhubungan dengan proses publikasi jurnal, dan juga mengefisiensienkan pencatatan dari proses editorial.[2].

\subsection{Content Management System (CMS)}

CMS Content Management System adalah merupakan sebuah platform perangkat lunak yang bisa memungkinkan user memanipulasi dan menambah isi dari suatu situs web. Maka demikian seorang editor atupun seorang penulis, setiap waktu dapat secara leluasa untuk menghapus, membuat, ataupun melakukan update isi dari suatu website tanpa adanya keterlibatan langsung pihak webmaster[4]. Server CMS (WCMS) merupakan system CMS pada saat ini banyak digunakan. WCMS marupakan sebuah sever perngakat lunak yang difungsikan dan dirancang sedemikian rupa sehingga memelihara/updating dan membangun sebuah web lebih efktif, mudah bagi orang mengerti ataupun orang yang tidak mengerti teknologi [5].

\subsection{Sistem Informasi}

Sistem informasi merupakan suatu sistem dalam suatu organisasi yang mempertemukan kebutuhan pengolahan transaksi harian yang mendukung fungsi operasi organisasi yang bersifat manajerial dengan kegiatan strategi dari suatu organisasi untuk dapat menyediakan kepada pihak luar tertentu dengan informasi yang diperlukan untuk pengambilan keputusan[6].

Menurut Whitten, Bentley, dan Ditman (2009:10) sistem informasi adalah pengaturan orang, data, proses, dan informasi (TI) atau teknologi informasi yang berinteraksi untuk mengumpulkan, memproses, menyimpan, dan menyediakan sebagai output informasi yang diperlukan untuk mendukung sebuah intansi atau organisasi[7].

\subsection{Metode Prototype}

Prototype Model merupakan suatu metode yang masih banyak digunakan untuk pengembangan perangkat lunak. Metode Prototyping merupakan seuatu metode yang memungkinkan pengembangan dan pelanggan untuk dapat saling berintraksi dalam proses pengembangan suatu sistem. Dalam metode ini pengembangan suatu sistem pelanggang seringkali hanya mendefinisikan apa saja kebutuhan sistem secara umum. Disisi pengembang, pegembang dalam mengembangkan sistem tidak terlalu memperhatikan Algoritma.[8].

Dalam pengembangan motede prototyping ada 3 proses yang dilewati, yakni sebagai berikut :

a. Pengumpulan kebutuhan: pengembang dan klien bertemu untuk membahas tujuan umum dari sistem yang akan di kembangkan, mulai dari kebutuhan kemudian gambaran bagian bagian yang akan di butuhkan untuk pengembangan

b. Perancangan: perancangan mewakili semua aspek software kebutuhan software yang diketahui dan dilakukan secara cepat, kemudian rancangan ini akan menjadi dasar dalam pembuatan prototype;

c. Evaluasi Prototype: klien mengevaluasi prototype yang dibuat dan digunakan untuk memperjelas kebutuhan software[9].

\subsection{Mean Opinion Score}

Pengujian MOS (Mean Opinion Score) digunakan untuk mendapatan hasil daro responden mengenai penlitian secara subjektif berdasarkan pengamatan hasil survey[10].

\section{Metode Pengabdian MaSyarakat}

\subsection{Metode Perancangan Sistem}

Model pengembangan yang digunakan pada pengembangan sistem ini adalah model Prototyping. Prototype Model merupakan seuatu metode yang memungkinkan pengembangan dan pelanggan untuk dapat saling berintraksi dalam proses pengembangan suatu sistem [8] seperti yang terlihat pada Gambar 1. 


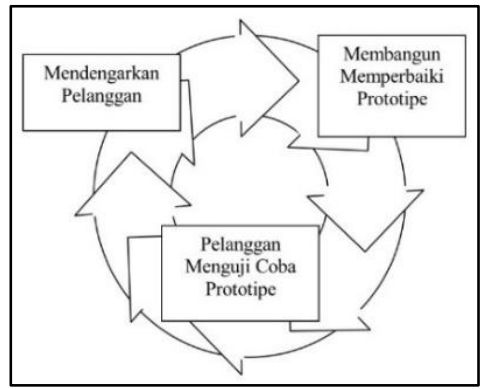

Gambar 1. Metode Penelitian Prototyping

\subsection{Analisis Kebutuhan}

Dalam perancangan model sistem IJPSS, maka perlu di lakukan diskusi dengan pihak pengelola OJS IJPSS guna menyesuaikan kebutuhan sistem yang di ajukan dan kebutuhan sistem yang dikumpulkan saat analisis kebutuhan. Sehingga model dalam merancang akan dibuat ke dalam Usecase, Squensial Diagram, Activity Diagram:

\subsubsection{Sistem sebelum di kembangkan}

a. Alur kerja sistem sebelum di kembangkan

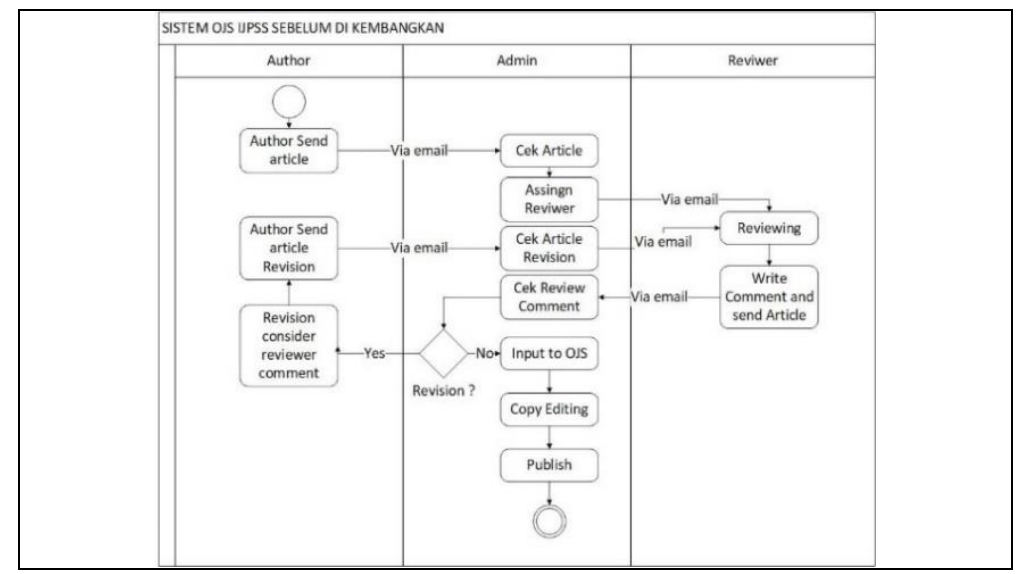

Gambar 2. Alur kerja sistem sebelum dikembangkan

Pada Gambar 2 dapat dilihat bawha dalam pengelolaan kerja sistem pada saat sebelum dikembangkan masih menggunakan sistem diluar sistem OJS. Pengelola melakukan pengecekan artikel, melakukan review-nya masih menggunakan via email, setelah selesai di-review kemudian admin mengunggah file tersebut ke dalam sistem OJS. Dalam proses pengecekan artikel dan proses review seharusnya di lakukan dalam sistem OJS, dan bukan admin yang melakukan pengimputan ke dalam sistem OJS. Hal ini dikarenakan masih kurangnya sumber daya pengelola mengenai bagaimana menjalankan sistem publikasi jurnal online.

b. Fitur sistem

Website IJPSS sendiri masih memiliki kekurangan dalam pembantu proses publikasi jurnal online, mulai dari pemberitahuan publikasi masih belum masih belum ada. Dengan tidak adanya fitur pengumuman menyebabkan sulitnya membuat pengumuman mengenai pemberitahuan publikasi. Kemudian dalam segi panduan publikasi untuk user Author masih belum ada yang mana dalam fitur ini akan ada bagaimana user Author akan bekerja sesuai dengan kebijakan yang sudah diatur oleh IJPPS. Hal lain yang harus di perhatikan adalah dari segi template untuk artikel masih belum ada yang menyebabkan setiap artikel tidak dalam satu format

\subsubsection{Sistem setelah di kembangkan}

a. Alur Kerja Sistem Setelah dikembangkan

Sistem dalam IJPSS setelah di kembangkan berjalan secara online pada sistem IJPSS, dalam proses pengiriman artikel oleh penulis masih di lakukan secara online di dalam sistem OJS, kemudian sistem 
reviewing sampai dengan proses publikasinya di lakukan secara online di sistem OJS IJPSS. Berikut pada Gambar 3 merupakan bagan yang menjekaskan sistem OJS IJPPS berjalan setelah dikembangkan.

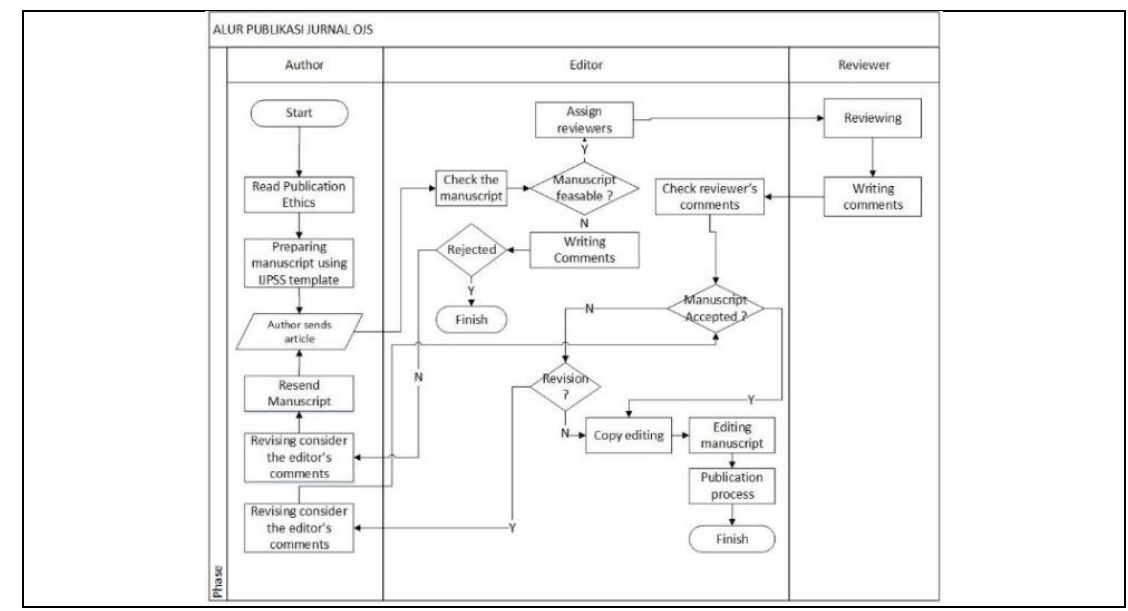

Gambar 3. Alur kerja sistem sebelum dikembangkan.

b. Fitur sistem

1. Fitur pengumuman

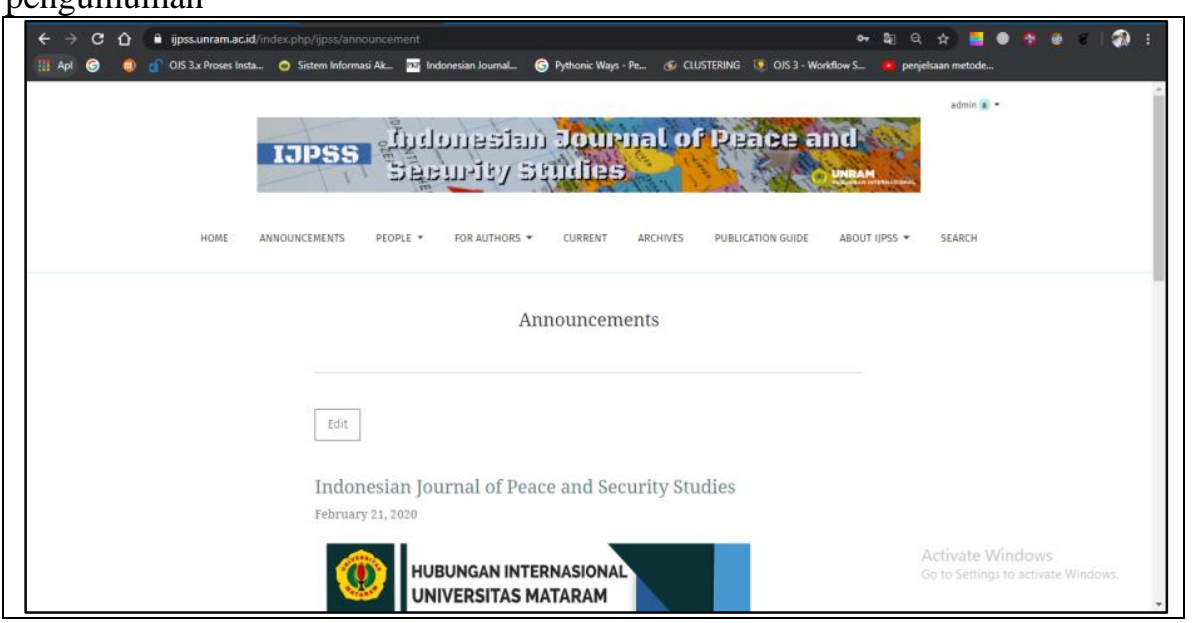

Gambar 4. Tampilan fitur pengumuman.

Tampilan pada Gambar 4 merupakan fitur pengumuman yang berfungsi untuk melakukan pengumuman akan adanya proses penerbitan jurnal, jadi penulis bisa mengirimkan tulisan hasil penlitiannya ke IJPSS (Call for Paper).

2. Fitur Panduan Publikasi

Tampilan pada Gambar 5 merupakan fitur yang berfungsi sebagai panduan publikasi untuk penulis dalam melakukan peng-unggahan artikel ke IJPSS. Pada halama ini juga akan ada syarat dan ketentuan untuk melakukan peng-unggahan aritikel, kemudia di halama ini juga aka nada bagaimana prosedur menjadi Author, dan Reviwer, hal ini untuk memudahkan para penulis cara menggunakan OJS. 


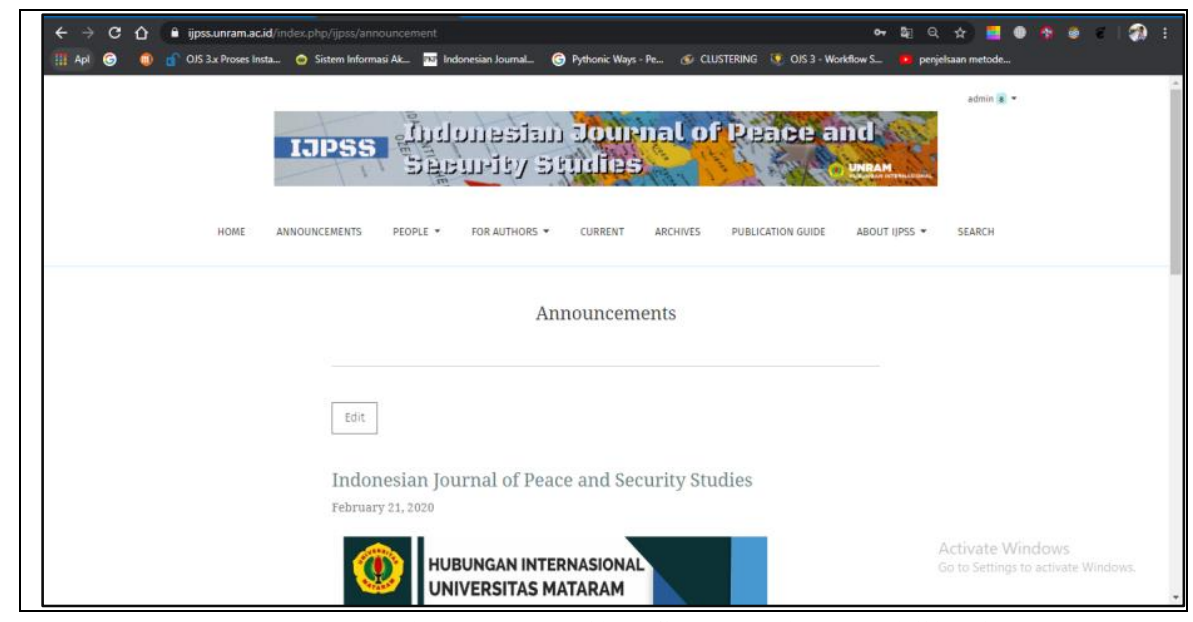

Gambar 5. Tampilan fitur panduan Publikasi.

\section{c. Manuscript Template}

Pada saat belum di kembang, pengelola menerbitkan jurnal yang yang mana dalam jurnal tersebut manuscript template masih tidak seragam. Pembuatan manuscript template di buat agar bentuk setiap bentuk tulisan sama dalam satu format jurnal. Manuscript template yang sudah di buat untuk IJPSS bisa dilihat pada halaman website online IJPSS pada bagian Auhtor's Guideline https://ijpss.unram.ac.id/index.php/ijpss/Guideline.

\subsection{Model Perancangan Sistem}

Dalam perancangan model sistem IJPSS, maka perlu di lakukan diskusi dengan pihak pengelola OJS IJPSS guna menyesuaikan dengan kebutuhan dari sistem yang diajukan dan kebutuhan sistem dari yang sudah dikumpulkan saat analisis kebutuhan. Sehingga model dalam merancang akan dibuat ke dalam Usecase, Squensial Diagram, Activity Diagram.

\subsubsection{Use Case Diagram}

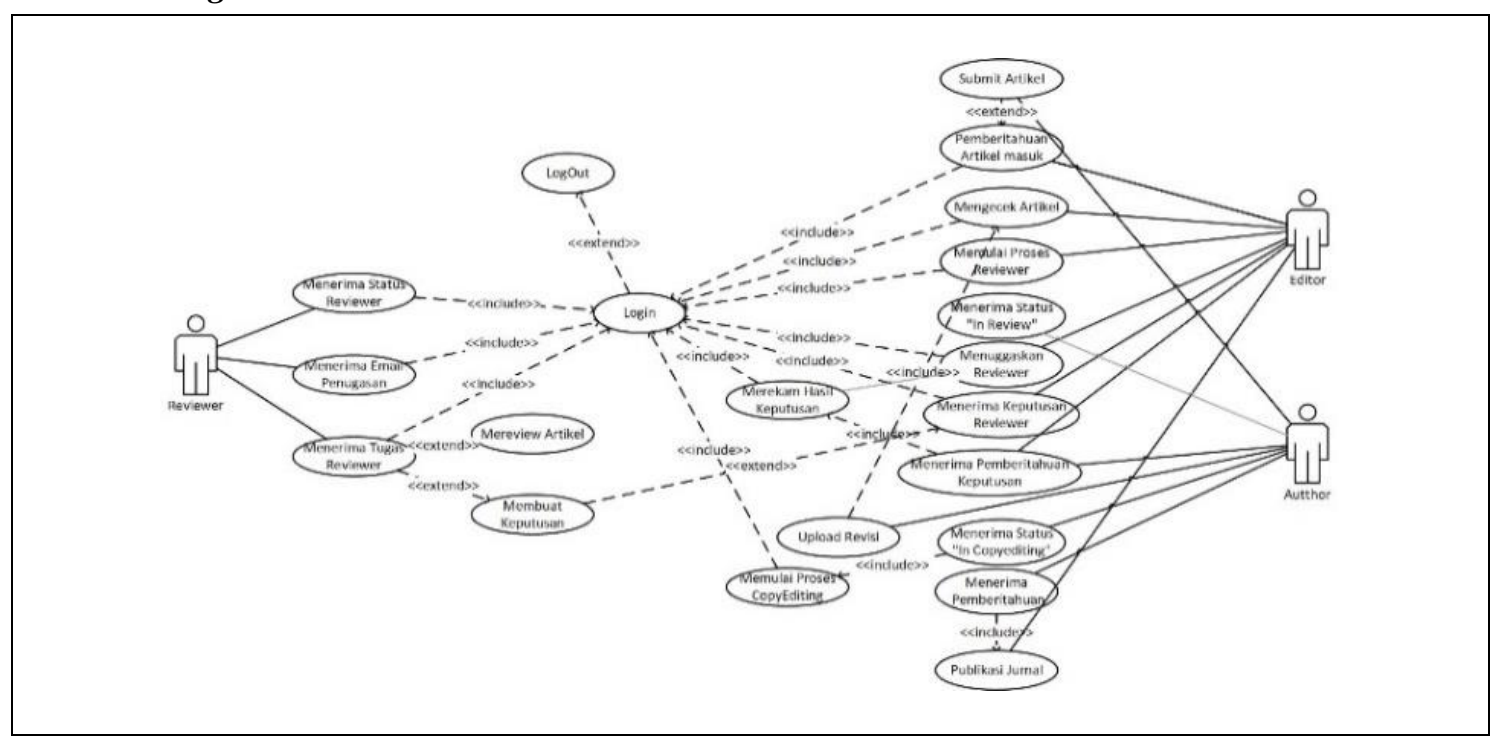

Gambar 6. Use Case Diagram.

Gambar 6 merupakan use case diagram dari sistem yang OJS IJPSS Hubungan Internasional Universitas Mataram yang sudah dikembangkan. Dalam use case diagram tesebut memiliki 3 user, yaitu Editor, Reviwer, dan Author. 


\subsubsection{Squence Diagram}

a. Proses pengecekan artikel oleh Editor

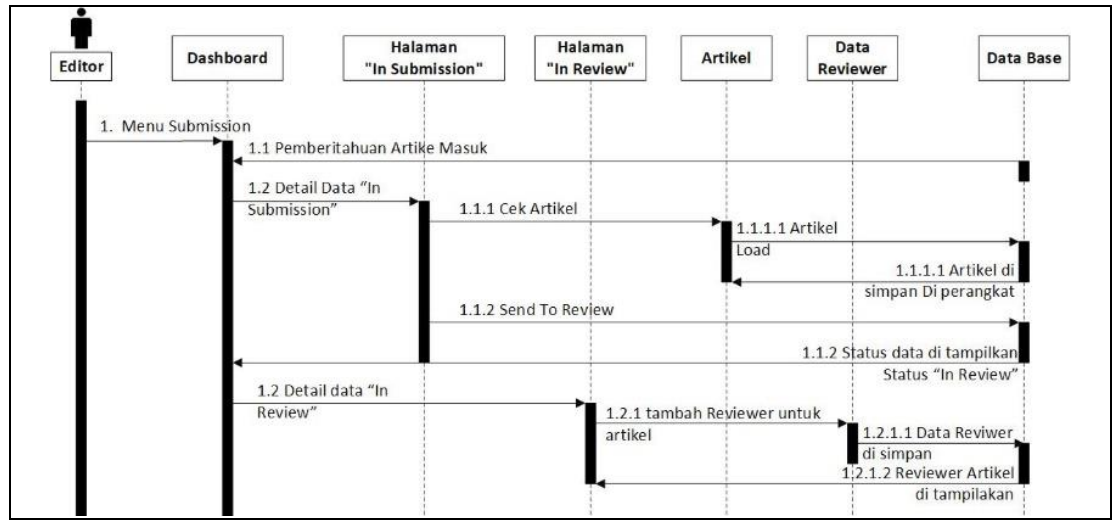

Gambar 7. Sequence diagram Proses pengecekan artikel oleh Editor.

Pada gambar 7 menjelaskan proses pengecekan artikel yang masuk oleh editor. Pada saat artikel sudah di unggah oleh author maka editor akan mendaptakan notifikasi terkait artikel yang baru masuk. Selanjutnya dari gambar diatas menjelaskan bahwa editor akan mengunduh file yang di unggah untuk di cek oleh editor. Setelah pengecekan selesai di lakukan maka artikel akan memasuki tahap review. Pada tahap ini editor terlebih dahulu memiliih reviewer untuk artikel tersebut. Setelah itu editor akan menunggu respon dari reviewer.

b. Proses Review Artikel oleh reviewer

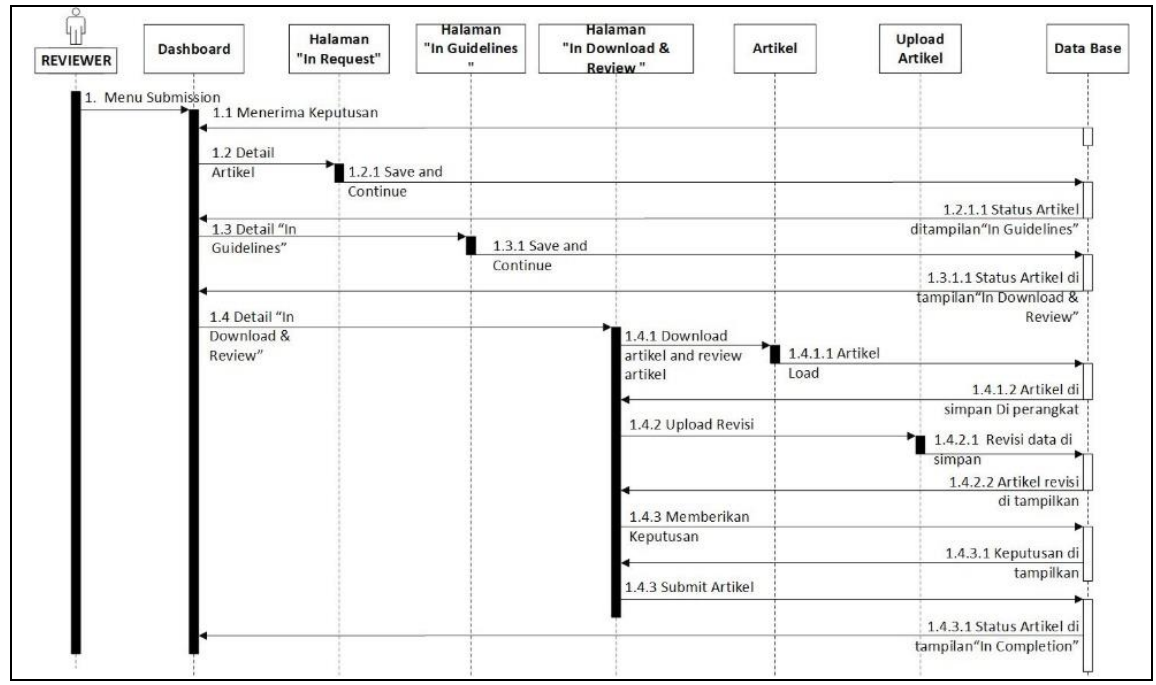

Gambar 8. Sequence diagram Review Artikel oleh reviewer.

Pada gambar 8 merupakan proses dari reviewer saat melakukan review artikel, pada saat artikel sudah dikirim ke reviewer oleh editor, maka reviewer mendapatkan email pemberitahuan penugasan, pada saat akan membuka detail dari artikel data maka reviewer akan di bawa menuju ke bagian Request yang mana reviewer bisa membaca semua detail penjelasan singkat data, mulai abstrack dan lainnya, Kemudian jika sudah setalah selesai pada bagian request maka selanjtunya akan di bawa menuju ke halaman guidelines. Pada bagian ini reviewer akan mendapatkan pedoman dalam me-review artikel yang akan di review. Setelah membaca guideline, maka selanjutnya akan menuju ke bagian Download \& Review, reviewer akan mengunduh dengan mengirim request unduh ke database kemudian database akan me-load data arikel, dengan otomatis browser yang anda gunakan akan menyimpan file pada perangkat reviewer. Setelah selesai me-review selanjutnya reviewer akan melampirkan file hasil review kedalam sistem lagi melalui fitur Upload revisi, yang mana hasil revisi sudah masuk ke sistem database akan tetapi belum di kirim ke editor. Setelah menguggah file hasil review, reviewer kemudian memberikan keputusan terikait artikel tersebut, hal ini akan menjadi patokan dalam pengolahan artikel oleh editor. 
Seteleh memberikan keputusan maka proses submit revisi di lakukan kemudian akan mengirim data revisi yang sudah ada di database ke bagian editor.

\subsubsection{Activity Diagram}

a. Pengecekan artikel oleh editor.

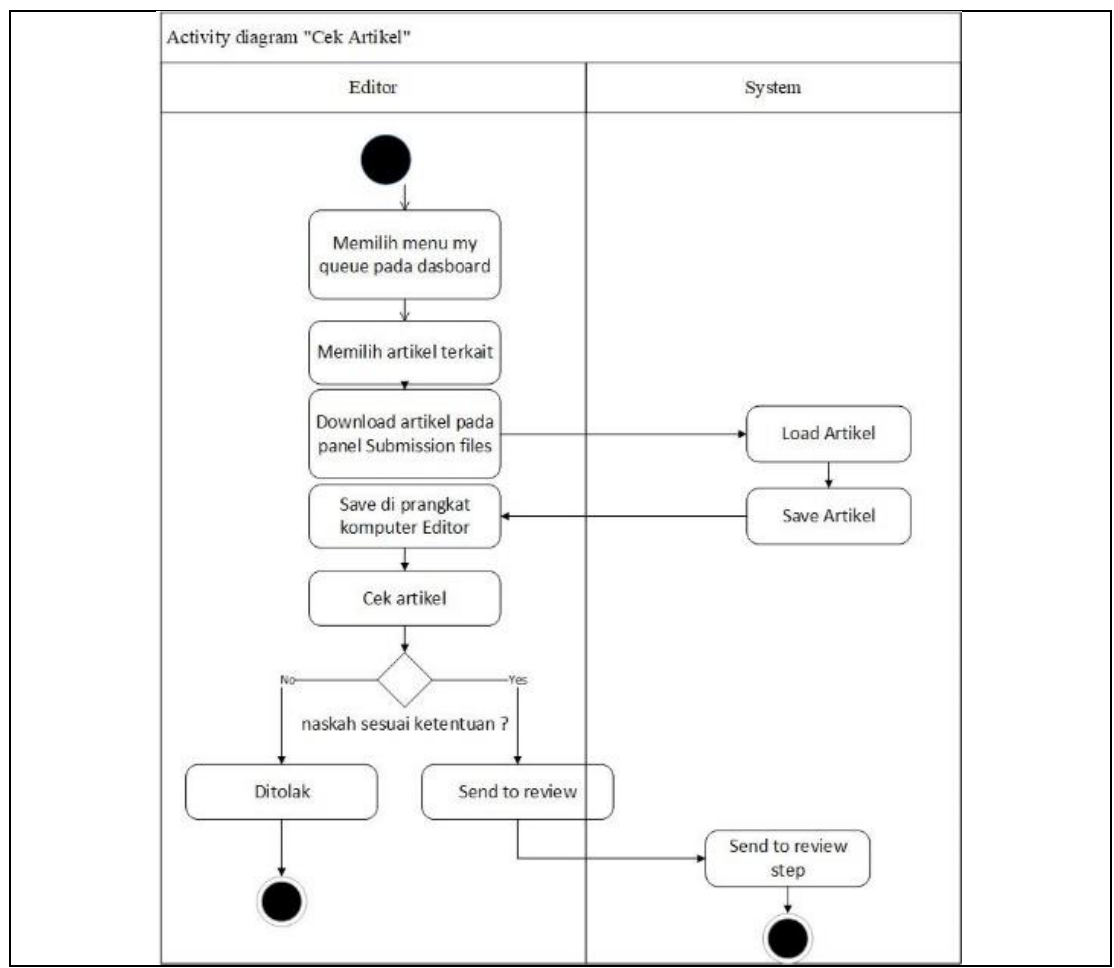

Gambar 9. Activity diagram Pengecekan artikel oleh editor.

Pada Gambar 9 menjelaskan proses pengecekan artikel yang sudah masuk oleh editor. Pada saat setelah melakukan login editor akan di bawa menuju halaman dashboard yang mana pada halaman dashboard terdapat list my queue yang berisikan list artikel yang masuk. Editor kemudian memilih artikel terkait maka editor akan di bawa menuju ke halaman tahap submission, pada tahap ini editor akan mendownload artikel untuk di cek pada panel submission file, kemudian sistem akan me-load data artikel, kemudian sistem akan menyimpan artikel pada perangkat komputer editor untuk di cek di luar sistem OJS. Setelah itu editor akan memberikan keputusan apakah artikel sudah masuk ketentuan apa tidak, jika artikel sudah masuk ketentuan maka artikel akan di kirim ke tahap review. Jika tidak masuk ketentuan maka artikel akan ditolak.

b. Review artikel oleh reviwer.

Pada Gambar 10 menjelaskan proses reviewer mereview artikel yang sudah masuk. Pada saat setelah melakukan login reviewer akan di bawa menuju halaman dashboard yang mana pada halaman dashboard terdapat list my queue yang berisikan list artikel yang masuk. Reviewer kemudian memilih artikel terkait maka reviewer akan di bawa menuju ke halaman tahap review, pada tahap ini reviewer akan mendownload artikel untuk di cek pada panel review file, sistem akan me-load data artikel, kemudian sistem akan menyimpan artikel pada perangkat komputer reviewer untuk di review di luar sistem OJS. 


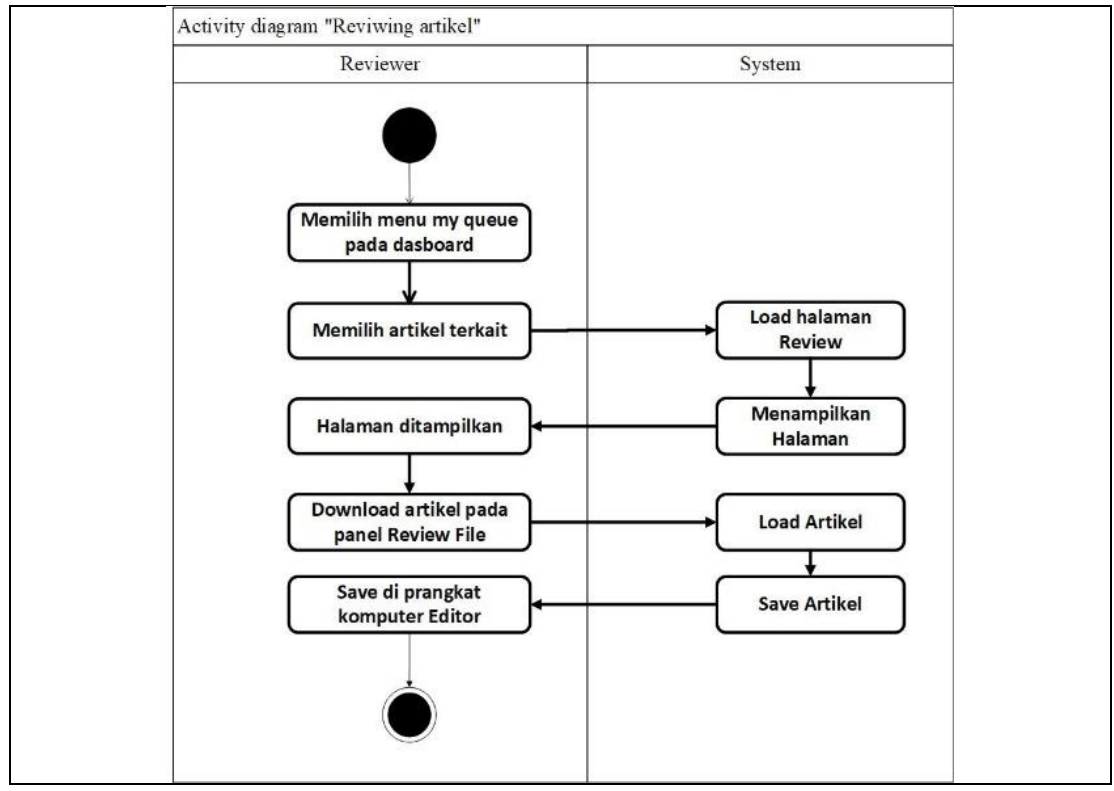

Gambar 10. Activity diagram Review artikel oleh reviewer.

\subsection{Menyesuaikan Sistem dengan kebutuhan user}

Pengembang menanyakan kepada klien tentang prototype dan Prosedur OJS yang sudah kembangkan, apakah prototype tersebut sudah sesuai atau tidak dengan kebutuhan sistem dan kebutuhan pengelola. Ketika belum sesuai maka akan kembali ke Analisa kebutuhan hingga sesuai dengan keinginan user. Untuk mengetahui hasil evaluasi dari pengelola maka akan di lakukan analisis melalui kuisoner kepuasan sistem. Dalam hal analisis maka akan di lakukan berdasarkan hasil dari responden setiap pertanyaan.

\subsubsection{Prosedur Penerbitan Jurnal OJS}

Untuk mengetahui kesesuian keinginan user terkait dengan prosedur yang sudah dibuat maka di buat pertanyaan terkait dengan prosedur penggunaa OJS. Adapun perntanyaanya "Prosedur OJS yang sudah dibuat menjelaskan semua prosedur penerbitan jurnal?"

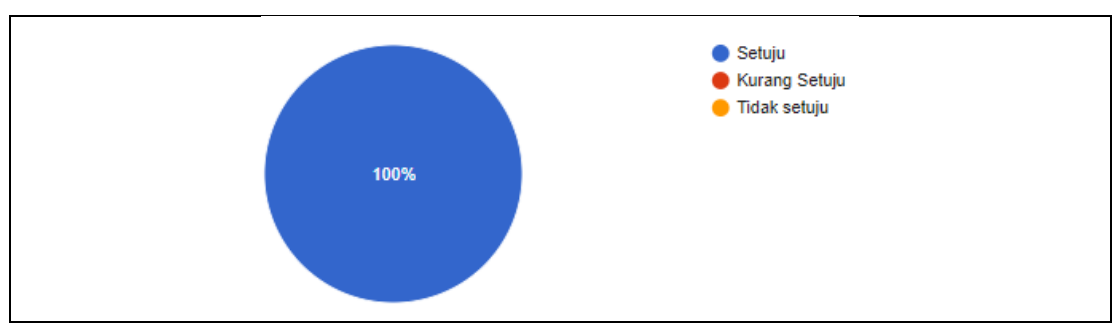

Gambar 11. Hasil Responden terikait prosedur OJS.

Data pada grafik menjelaskan kepuasan pengelola OJS IJPSS terhadap prosedur sistem yang sudah di buat, jika dianalisis dari grafik maka bisa di lihat semua responden setuju bahwa prosedur OJS yang sudah di buat menjelaskan semua prosedur.

\subsubsection{Fitur yang dikembangkan untuk mempermudah dalam memproleh informasi}

Untuk mengetahui kesusaian keinginan user terkait dengan fitur yang sudah dikembangkan apakah sudah dapat memberikan informasi yang detail atau tidakmaka di buat pertanyaan terkait dengan informasi yang didapatakn. Adapun perntanyaanya "Sistem informasi menghasilkan informasi yang detail?". 


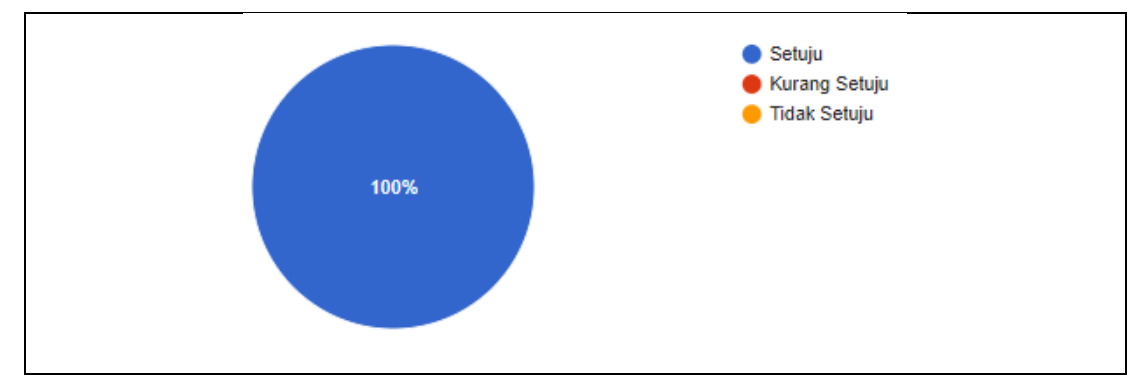

Gambar 12. Hasil Responden terikait Pengelolaan informasi.

Data pada grafik menjelaskan kepuasan pengelola OJS IJPSS terhadap mendapatkan infomasi, jika di analisis dari grafik maka bisa dilihat semua responden setuju bahwa OJS yang sudah dikembangkan memberikan informasi yang detail.

\subsection{Implementasi Sistem}

Sistem yang sudah dikembangkan akan mulai di implentasikan dimana jika kondisi prototype yang telah dikembangkan sudah sesuai dengan keinginan pengelola IJPSS yang mana berperan sebagai klien. Apabila prototype yang telah di kembangkan sesuai dengan kebutuhan klien, maka prototype tersebut bisa langsung diimplentasikan untuk proses penerbitan jurnal secara online.

\section{HaSil dan PEMbahasan}

Setelah dilakukan percobaan untuk pengimplementasian sistem selanjutnya dilakukan pengujian sistem untuk mengetahui kepuasan dari pengelola OJS IJPSS. Pengujian dengan menggunakan kuisoner dilakukan dengan memberikan kuisoner kepada pengelola OJS IJPSS untuk menguji kepuasannya terhadap sistem. Parameter pengujian yang digunakan pada metode ini adalah :

a. Prosedur OJS yang sudah dibuat menjelaskan semua prosedur penerbitan jurnal?

b. Sistem yang dikembangkan mudah digunakan?

c. Sistem informasi sangat mudah diakses dari semua komputer?

d. Sistem informasi menghasilkan informasi yang detail?

e. Dalam hal tata lekat (display) sistem mudah untuk di baca?

f. Informasi yang diberikan dapat diandalkan/dipercaya?

Selanjutnya responden yang mana klien itu sendiri akan disediakan pilihan jawaban dari setiap pertanyaan yang ada, yaitu :
a. $\mathrm{S}=$ Setuju
b. $\mathrm{CS}=$ Cukup Setuju
c. TS = Tidak Setuju

Hasil rekapitulasi jawaban responden dihitung dari jawaban berdasarkan pengisian kuesioner dari masingmasing pernyataan. Berikut gambar untuk grafik persentase jawaban rata-rata hasil pengujian dari 3 responden,

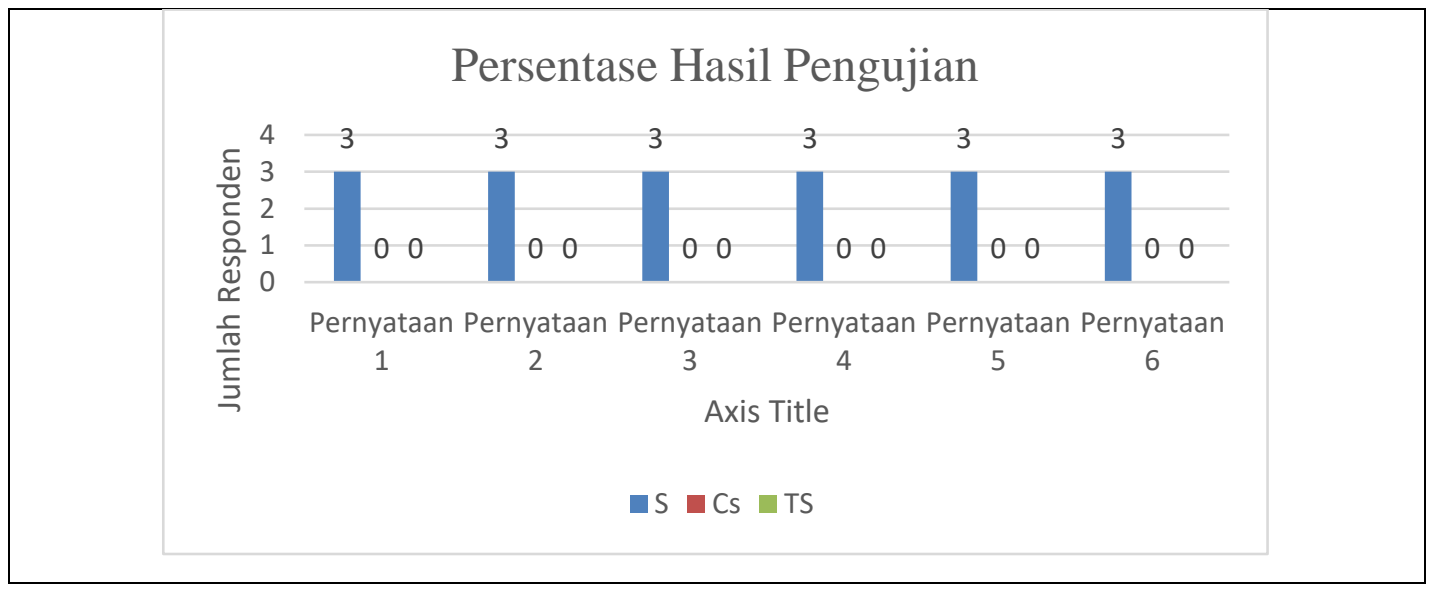

Gambar 15. Persentase hasil pengujian 
Pada Gambar 15 merupakan hasil dari persentase pengujian dari kuesioner yang diberikan mendapatkan nilai untuk pernyataan nomor 1 Semua responden setuju dengan pertanyaan 1, nilai untuk pernyataan nomor 2 Semua responden setuju dengan pertanyaan 2, nilai untuk pernyataan nomor 3 Semua responden setuju dengan pertanyaan 3 , nilai untuk pernyataan nomor 4 Semua responden setuju dengan pertanyaan 4 , nilai untuk pernyataan nomor 5 Semua responden setuju dengan pertanyaan 5, dan nilai untuk pernyataan nomor 6 Semua responden setuju dengan pertanyaan 6. Maka dapat simpulkan dari hasil pengujiannya bahwa hasil dari kepuasan terhadap sistem yang sudah dikembangkan setuju untuk sistem OJS yang dikembangkan diimplementasikan.

\subsection{Kesimpulan}

\section{KESIMPULAN DAN SARAN}

Pada Pengabdian Masyarakat di Lembaga Penelitian dan Pengabdian Program Studi Hubungan Internasional Universitas Mataram berupa Sosialisasi dan pengembangan OJS IJPSS didapatkan kesimpulan sebagai berikut:

a. OJS memiliki beberapa jenis user yang mengatur proses editorial dan publikasi ilmiah e-journal, antara lain yaitu penulis, editor, reviewer, pembaca.

b. OJS memiliki beberapa tahap dalam proses editorial dan publikasi ilmiah e-journal, antara lain yaitu tahap pengencekan kesusain artikel dengan ketentuan yang berlaku, proses review, proses copyediting, dan proses production.

c. OJS memiliki beberapa fitur pendukung untuk bisa menerbitkan 1 edisi jurnal, seperti, fitur pengumuman untuk call for paper, fitur panduan publikasi yang berisikan prosedur dan ketentuan untuk penerbitan jurnal, dan panduan Manuscript Template untuk format artikel yang akan diolah.

\subsection{Saran}

Setelah di lakukannya Pengabdian Masyarakat ini, penulis memiliki saran yang dapat diberikan untuk Sistem OJS ini jika akan di kembangkan menjadi lebih baik kembali di masa mendatang berikut saran dari penulis:

a. Perlunya dilakukan Analisa dan pengembangan prosedur pengolahan dan perawatan sistem dari segi admin.

b. Dalam perawatan sebaiknya menggunakan OJS versi stabil dan mendukung penuh kebutuhan. Agar tidak menjadi beban untuk pengembangan selanjutunya, maka sistem ini harus tetap di perbaharui mengikuti versi terbaru dari OJS.

\section{DAFTAR PUSTAKa}

[1] P. Hidayattullah, "Pemrograman Web," Bandung: Informatika Bandung, 2014.

[2] Fakultas Keguruan dan Ilmu Pendidikan. t.t, "FKIP UNS Journal Systems", 2020 [Daring]. Tersedia pada : https://jurnal.fkip.uns.ac.id/public/journals/Modul-OJS-fkipuns.pdf. [Diakses : 23-apri-2020].

[3] A. Fadli, "Tata Kelola Jurnal Elektronik di Institusi Pendidikan Tinggi Berbasis Framework OJS - Sesi 2," pp. 16, 2019.

[4] L. K. Scott, "Perancangan Dan Pembuatan Content Managemen System (Cms) 'Barca Cms' Menggunakan Framework Codeigniter," vol. 13, no. 3, 2013.

[5] D. Wijaya, "Content Management System," vol. 20, no. 1, 2009.

[6] Gita Oktavianti, "Pengantar Sistem Informasi," Pengantar Sist. Inf., vol. 2, no. March, p. 31, 2019.

[7] Asriyanik, "Penilaian Keamanan Sistem Informasi Akademik Universitas Muhammadiyah Sukabumi Dengan Menggunakan ISO 27001,” J. Ilm. Sains dan Teknol., vol. 6, no. 2, pp. 501-506, 2016.

[8] T. Hayani, "Aplikasi Media Pembelajaran Huruf Iqro Berbasis Multimedia," pp. 1-17, 2017.

[9] M. Ali, "Model Pengembangan Perangkat Lunak," p. 28, 2018.

[10] B. Irmawati, P. Studi, T. Informatika, F. Teknik, and U. Mataram, "( The Analysis System Students Satisfaction Level Toward Teaching and Learning," vol. 1, no. 1, pp. 31-40, 2019. 